\title{
Briefing: Why knowledge-based construction is needed for a $1.5^{\circ} \mathrm{C}$ world
}

Keith Clarke CBE, FICE, HonFRAEng, MRIBA, Dip Arch, MSc

Chair, Future Cities Catapult, London, UK; Chair, Forum for the Future,

London, UK; Chair, Tidal Lagoon Swansea Bay, Swansea, UK

(keithefclarke@gmail.com)

Most countries in the world have agreed to limit the average global temperature change to $2^{\circ} \mathrm{C}$, with an aspiration to keep it to $1.5^{\circ} \mathrm{C}$. Constructing the built environment for the additional three-to-four billion people on the planet, accommodating the roughly three billion who will expect to join the 'middle class' and meeting the United Nations' development goals are all fantastic challenges and arguably could be met by the existing industry by trying harder. Add reducing the carbon dioxide emissions of the global economy very, very quickly as a conditioner on all of the above, and a different industry is both required and likely to emerge.

\section{Introduction}

The progress made on reducing global poverty has been significant but still leaves around $10 \%$ of the population of the world living on less than US\$1.90 a day (World Bank, 2015). This, married with some three billion people living on less than US $\$ 2.50$ a day (Shah, 2013), at first sight would seem where the provision of infrastructure should be entirely focused. This Briefing outlines what is the overarching conditioner of these issues and describes the basic business models that exist in the industry, why without a radical change the objectives of limiting the average global temperature increase to $1 \cdot 5^{\circ} \mathrm{C}$ cannot be met (UNFCC, 2015a) and lastly why a confluence of need and technology may bring about such changes.

\section{Context}

The global population will grow to somewhere between 9 and 11.5 billion people by 2050 , putting massive strains on natural resources (Desa, 2015). While the engineering community can continue to provide answers in the traditional manner by building more (where societies have the funds), it has no role in limiting the growth, which lies in the emancipation of women (albeit the engineering profession remains a late starter compared to medicine, accounting, law and healthcare).

Urbanisation will continue; the UN estimates that more than $70 \%$ of the world's population will be living in some form of urban communities (Desa, 2011). Again, engineering can create more and bigger cities; whether they are equitable or sustainable is another question. As part of this urbanisation, some three billion people plus will achieve middle-class status (Pezzini, 2012) - that is, become consumers who have choice!

This is what will require a move to a knowledge-based construction industry. If three billion people become middle class with the carbon dioxide intensity that society currently enjoys, the world will not achieve $1 \cdot 5^{\circ} \mathrm{C}$, nor $2^{\circ} \mathrm{C}$, but society is careering towards the $4^{\circ} \mathrm{C}$ scenario.
This is where and how the infrastructure is provided for this combination of urbanisation and middle-class growth conditions and the ability to achieve virtually all of the UN Development Goals. The $4^{\circ} \mathrm{C}$ scenarios are highly volatile, with clear impacts on rainfall, extreme weather events, crops, social stability and so on. Alas, a rapid and revolutionary reduction of the carbon dioxide $\left(\mathrm{CO}_{2}\right)$ emissions ('decarbonisation') of the global economy in the next 30 years will not in itself provide relief from abject poverty, inequality, racial and gender discrimination and extremism, but the failure to do so makes progress on these issues extremely difficult if not impossible.

According to the Organisation for Economic Co-operation and Development (OECD, 2015), society will be spending some US $\$ 70$ trillion on infrastructure by 2030 (i.e. about six new Europes in terms of built environment), the need to do so not only adapting to climate change (a privilege for the wealthier parts of society) but also massively mitigating the carbon dioxide emission intensity of both the construction and, more significantly, the operation of such infrastructure is paramount.

A recent debate at the Institution of Civil Engineers on whether the engineering profession was fit to provide a low-carbon-dioxide future had the majority of the audience voting 'No'. Trying harder will give rise to what it has historically done; bigger answers to the same questions - that is, adaptation leads and mitigation is neglected to an afterthought. Capital expenditure (Capex), not operating expenditure (Opex), will continue to dominate, and the existing business models of designers, cash positive general contractors and sub-contractors will continue with only marginal improvements and no real innovation.

So what will cause a change and to what? There is the landmark Paris Agreement (UNFCC, 2015b), for which, being one of the facilitators, the UK can claim enormous credit. Sir David King and his team in the Foreign and Commonwealth Office should take a well-deserved bow for this. The UK has the Climate 
Smart Infrastructure and Construction

Volume 170 Issue SC
Briefing: Why knowledge-based

construction is needed for a $1.5^{\circ} \mathrm{C}$ world

Clarke
Change Act 2008 (endorsed by all three parties) and it has advances in technology.

It is not only where but how we provide big data, combined with scenario modelling and building information modelling (BIM), that gives an opportunity to radically change the business models where the emerging designer/assembler team works with manufacturers who install increasingly integrated systems to both infrastructure (loosely defined as the stuff in and on streets that move things) and building.

The only part of the construction supply chain regularly investing in intellectual property are asset-based or technology-based firms, not traditional consultancies nor general contractors but manufacturers, and one can expect a rapid emergence of technology companies such as Google, Apple and Tesla moving into existing traditional areas such as the automotive industry and disrupting the traditional design, bid, construct and argue process.

It is hard to see how the existing collection of business models can incorporate quickly, safely and reliably a fundamental design parameter - that is, carbon dioxide emissions - for both Opex and Capex efficiently. Disruptions are occurring in other sectors, and a wise profession would look to mandate basic skills in anticipation so that professionals as individuals have some ability to make a leap. It would not be unreasonable for all PEIs to mandate as part of continuing professional development that all members undertake basic courses in the outcome of 21 st Conference of the Parties to the UN Framework Convention on Climate Change and its obligations, not only to adapt but also to mitigate climate change - a basic starting point! Legal \& General are writing to all chairmen of companies that they invest in, asking what their boards are doing to respond to climate change. Society is moving rapidly from decarbonisation being a corporate frill to it being fundamental to the viability and future of companies.

Using BIM just as a smarter drawing board (as most computeraided design systems have been used) does not do it. Changing the design process requires larger integrated teams at the beginning, early selection not of contractors but manufacturers and suppliers who will develop installation capabilities. This allows carbon dioxide emissions to be a primary design determinant for both Capex and Opex. This change will happen; it is just not clear what type of enterprises will thrive and who will not. All significant changes create winners and losers; the construction industry cannot pretend it is immune to this.

What then remains is to convince government, clients and funders to evaluate Opex as a more significant criterion (factoring in carbon dioxide emissions) than Capex is. Capex will continue to dominate infrastructure decisions; witness Jubilee, Crossrail, High Speed 1 and High Speed 2 debates about routes and stations - all of which are about Capex! Technology will provide real-time monitoring of infrastructure's actual carbon dioxide emissions performance in use, with significant research under way in this area. Link this to funding costs in real time, and city leaders may suddenly be requesting whole-life operational efficiency as a design determinant at the start and the Treasury could even appraise in that light.

It is simple, really. The year 2017 will be an interesting one for those who embrace change and a challenging year for those who do not.

\section{REFERENCES}

Climate Change Act 2008. Chapter 27. Her Majesty's Stationery Office, London, UK.

Desa (Department of Economic and Social Affairs) (2011) Population Distribution, Urbanization, Internal Migration and Development: an International Perspective. Desa, New York, NY, USA. See http:// www.un.org/esa/population/publications/PopDistribUrbanization/ PopulationDistributionUrbanization.pdf (accessed 14/03/2017).

Desa (2015) World Population Prospects: the 2015 Revision. Desa, New York, NY, USA. See https://esa.un.org/unpd/wpp/publications/files/ key_findings_wpp_2015.pdf (accessed 14/03/2017).

Pezzini M (2012) An emerging middle class. OECD Observer. See http:// oecdobserver.org/news/fullstory.php/aid/3681/An_emerging_middle class.html (accessed 14/03/2017).

OECD (Organisation for Economic Co-operation and Development) (2015) Fostering Investment in Infrastructure: Lessons Learned from OECD Investment Policy Reviews. OECD, Paris, France. See https://www.oecd.org/daf/inv/investment-policy/FosteringInvestment-in-Infrastructure.pdf (accessed 14/03/2017).

Shah A (2013) Poverty Facts and Stats. See http://www.globalissues.org/ article/26/poverty-facts-and-stats (accessed 14/03/2017).

UNFCC (UN Framework Convention on Climate Change) (2015a) Adoption of the Paris Agreement. UNFCC, Bonn, Germany. See https://unfccc.int/resource/docs/2015/cop21/eng/109.pdf (accessed 14/03/2017)

UNFCC (2015b) Paris Agreement. UNFCC, Bonn, Germany. See http:// unfccc.int/paris agreement/items/9485.php (accessed 29/03/2017).

World Bank (2015) FAQs: Global Poverty Line Update. World Bank, Washington, DC, USA. See http://www.worldbank.org/en/topic/ poverty/brief/global-poverty-line-faq (accessed 14/03/2017).

\section{How can you contribute?}

To discuss this paper, please email up to 500 words to the editor at journals@ice.org.uk. Your contribution will be forwarded to the author(s) for a reply and, if considered appropriate by the editorial board, it will be published as discussion in a future issue of the journal.

Proceedings journals rely entirely on contributions from the civil engineering profession (and allied disciplines).

Information about how to email your paper online is available at www.icevirtuallibrary.com/page/authors, where you will also find detailed author guidelines. 